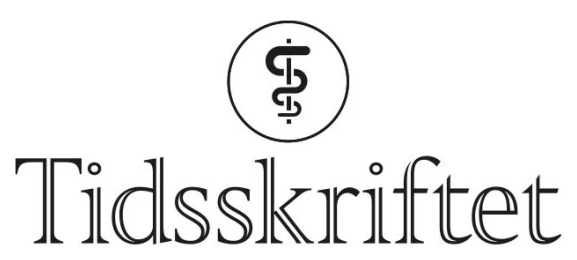

DEN NORSKE LEGEFORENING

\title{
Syfilis og transfusjon
}

\author{
BREV TIL REDAKTØREN
}

HANS ERIK HEIER

Oslo universitetssykehus, Ullevål

PÅL A. JENUM

Vestre Viken HF

I Tidsskriftet nr. 8/2010 omtalte Jenum og medarbeidere en hendelse der syfilis ble påvist hos en etablert norsk blodgiver da denne byttet blodbank (1). Alle gjeldende rutiner for syfilistesting var fulgt. Et ekspertutvalg under Helsedirektoratet har vurdert om tilfellet gir grunnlag for endrede rutiner for syfilistesting av blodgivere og har konkludert med ikke å anbefale endringer. Dette innebærer at blodgivere bare testes for syfilis ved registrering som ny giver. Retesting skjer bare hvis giveren flytter til en annen blodbank og blir nyregistrert der.

I artikkelen angis det at blodbanken som giveren forlot (Blodbank B), testet hele giverkorpset for syfilis som følge av det inntrufne og at man ikke fant smittsom syfilis blant giverne. Undersøkelsen ble oversendt Helsedirektoratet og var tilgjengelig for ekspertutvalget og forfatterne. Den er også publisert som kongressreferat (므). Dessverre ble ikke Blodbank B informert om at artikkelen (1) var under skriving, og den fikk derfor ikke anledning til å informere om at det $\mathrm{i}$ korpset ble funnet en giver med spor etter syfilis. Det refereres heller ikke at Blodbank B anbefalte endring av gjeldende rutiner for syfilistesting. Den anbefalte å innføre rutinemessig retesting av givere som har vært fraværende fra givning mer enn seks måneder, tilsvarende rutinen som gjelder for testing på antistoff mot hepatitt B-kjerneantigen. Da vil man ha større sjanse for å fange opp givere som er blitt syfilissmittet og har holdt seg unna givning en tid fordi de har erkjent at de har vært i en smitterisikosituasjon. Vi vil likevel påpeke at selv ved tapping av smittsom giver er overføring av syfilis svært lite sannsynlig(스).

Syfilistesting er billig og en endring som anbefalt av Blodbank B, vil gi liten utgiftsøkning for blodbankene. Samlet sett bør Blodbank Bs anbefaling tas opp til ny realitetsvurdering. Verdens helseorganisasjon anbefaler testing for syfilis ved hver givning (3), mens Europarådsguiden (4) og den norske blodforskriften ikke har krav om testing (5). 


\section{LITTERATUR}

1. Jenum PA, Flesland $\emptyset$, Blystad $\mathrm{H}$ et al. Syfilis og blodtransfusjon. Tidsskr Nor Legeforen 2010; 130: 839-41.

2. Grosz D, Hetland G, Skar AG et al. Retesting Oslo blood donors for syphilis. Vox Sang 2009; 96 (suppl 1): 98 .

3. World Health Organization. Screening donated blood for transfusion-transmissible infections. Recommendations. Genève: World Health Organization, 2009.

4. The European Directorate for the Quality of Medicines \& HealthCare. Guide to the preparation, use, and quality assurance of blood components. 15 utg. Strasbourg: EDQM, 2010: 128, 291-2.

5. Forskrift om tapping, testing, prosessering, oppbevaring, distribusjon og utlevering av humant blod og blodkomponenter og behandling av helseopplysninger i blodgiverregistre (Blodforskriften). §3-9. http://lovdata.no/cgi-wift/wiftldles?doc=/app/gratis/www/docroot/for/sf/ho/ho-20050204oo8o.html\&emne=blodforskrift*\&\& (19.10.2010).

Publisert: 18. november 2010. Tidsskr Nor Legeforen. DOI: 10.4045/tidsskr.10.1016

(C) Tidsskrift for Den norske legeforening 2023. Lastet ned fra tidsskriftet.no 26. april 2023. 